Review

\title{
Benthic Foraminifera as Environmental Indicators in Mediterranean Marine Caves: A Review
}

\author{
Elena Romano $^{1, *(\mathbb{D})}$, Luisa Bergamin ${ }^{1}(\mathbb{D})$ and Mario Parise ${ }^{2}$ (D) \\ 1 ISPRA, Institute for Environmental Protection and Research, Via Vitaliano Brancati 60, 00144 Rome, Italy; \\ luisa.bergamin@isprambiente.it \\ 2 Earth and Environmental Sciences Department, University Aldo Moro, Via Orabona 4, 70125 Bari, Italy; \\ mario.parise@uniba.it \\ * Correspondence: elena.romano@isprambiente.it
}

check for

updates

Citation: Romano, E.; Bergamin, L.;

Parise, M. Benthic Foraminifera as

Environmental Indicators in

Mediterranean Marine Caves: A

Review. Geosciences 2022, 12, 42.

https://doi.org/10.3390/

geosciences 12010042

Academic Editors:

Rossana Sanfilippo,

Maria Triantaphyllou and

Jesús Martínez-Frías

Received: 5 November 2021

Accepted: 13 January 2022

Published: 16 January 2022

Publisher's Note: MDPI stays neutral with regard to jurisdictional claims in published maps and institutional affiliations.

Copyright: (c) 2022 by the authors. Licensee MDPI, Basel, Switzerland. This article is an open access article distributed under the terms and conditions of the Creative Commons Attribution (CC BY) license (https:// creativecommons.org/licenses/by/ $4.0 /)$.

\begin{abstract}
Marine caves are characterized by wide environmental variability for the interaction between marine and continental processes. Their conditions may be defined as extreme for inhabiting organisms due to the enclosed morphology, lack of light, and scarcity of nutrients. Therefore, it is necessary to identify reliable ecological indicators for describing and assessing environmental conditions in these habitats even more than elsewhere. This review aims to provide the state of art related to the application of benthic foraminifera as proxies in the (paleo)ecological characterization of different habitats of marine caves. Special attention was addressed to a research project focused on Mediterranean marine caves with different characteristics, such as extent, morphology, freshwater influence, salinity, sediment type, oxygenation, and organic matter supply. This review aims to illustrate the reliability of foraminifera as an ecological and paleoecological indicator in these habitats. They respond to various environmental conditions with different assemblages corresponding to a very detailed habitat partitioning. Because marine caves may be considered natural laboratories for environmental variability, the results of these studies may be interpreted in the perspective of the global variability to understand the environmental drivers of future changes in marine systems.
\end{abstract}

Keywords: benthic foraminifera; marine caves; ecological indicators; paleoecological reconstruction; Mediterranean Sea

\section{Introduction}

\subsection{General Characteristics of Marine Caves}

Karst aquifers are among the most significant freshwater supplies for human consumption [1-3], with recent estimates indicating that over $9 \%$ of the global population is partly or entirely supplied by karst freshwater [4,5]. As for coastal aquifers, such a resource becomes even more important, being often the only one available to communities living therein [6-9]. Furthermore, the karst aquifers' emergence frequently occurs through submarine freshwater springs. Therefore, study and monitoring become essential to understanding the modality of formation of the cave passages and fully comprehend the hydrogeology of the watersheds feeding the springs $[10,11]$.

Caves observed in coastal areas may be of classical karst origin [12,13] or can be formed through a variety of other processes. In this second case, they are generally attributed to the category of pseudokarst caves since they may involve rocks different than carbonates. For instance, marine caves, produced by the action of sea waves, consist typically of single chambers of limited development, opened to the sea; their later development often occurs through failure mechanisms, with the detachment of further masses of rocks from the cliffs, or through the opening of sinkholes at the surface, along the coast or in nearby areas [14-18], with sinkholes often providing the inland entrance to the system. Still, regarding cliff retreats, weathering processes play an important part in their predisposition 
to erosion and failure mechanisms [19-24] and the presence of discontinuity systems, also related to the development of tensional release cracks to the continuous action of sea waves.

Karst caves along the coast may originally have formed inland by freshwater dissolution processes, whilst nowadays they are interacting with the present coastal environment. Their current location is inevitably related to the sea level position, but this, in turn, depends on various factors, such as tectonic uplift or isostasy, or eustatic sea-level changes, with the latter of these significantly caused by glacio-eustasy [25]. In terms of speleogenesis, in the vadose (unsaturated) zone, a cave development is much different from what happens in the phreatic (saturated) zone [26,27]. If we go below the groundwater table into the phreatic zone, the present phreatic coastal caves can be classified as littoral, anchialine, or submarine [28]. Further distinctions can be made based on sedimentary and microfossils characters, as proposed by van Hengstum and Scott [29], but based only on environmental conditions, without considering any genetic issues [30].

The majority of coastal karst caves are in warm latitudes in relatively young carbonates [31,32]. This means that the rocks are typically no older than the Miocene, and are today exposed because of tectonic causes or due to past higher glacio-eustatic conditions; such recent rock masses have a significant porosity (greater than 30\%), with void connection creating high permeability, since they have had no time to become compact carbonate rocks through diagenetic processes. In contrast to the older and mature rocks (telogenetic), they were defined by Choquette and Pray [31] as eogenetic. These porosity and permeability characteristics allow for the mixing of water to occur through the whole rock mass, and not be limited to the main discontinuity systems.

The world's highest number of marine caves is formed through the flank margin cave model $[33,34]$. This requires mixing freshwater with sea water and the effects of sea-level changes produced by glacio-eustatic or local causes, typically affecting eogenetic carbonates. A freshwater lens in coastal environments is produced by the difference in density between freshwater and sea water [35,36]: the first floats on the latter, with a physics explained by the well-known Ghyben-Herzberg model. The boundary separating the two is a halocline or a transition zone where gradual brackish water separates the two bodies. The lens's thickness decreases toward the coast, and, consequently, the flow velocity increases [37,38]. This is exactly the sector where carbonate dissolution is the strongest, as an effect of the thin lens and the abundant organic material entering the system through vadose flow at the top and bottom of the lens itself. Decay of the organic material enhances dissolution, which is further favored by superimposition over a short vertical distance of the mixing water zone along the coast. As a whole, this allows for the development of flank margin caves $[34,39]$ through a single formation event, without additional phreatic overprinting.

The morphological features presented by flank margin caves at the Bahamas have become the morpho-type for identifying caves of similar origin in other parts of the world: they have been used as indicators of both past sea-level position and tectonic stability by Carew and Mylroie [40], and represent the best example for the simple carbonate island model [33].

In flank margin caves, flow is non-turbulent since water goes in and out of the caves as diffuse or laminar flow, thus resulting in an absence of high-velocity structures and turbulent flow wall sculptures, including scallops, as well as of sediments [41,42]. Generally, these caves have no entrance for humans, and access is only later on allowed due to cliff retreat and erosional processes.

Sea level changes cause a direct variation in the position of the freshwater lens. Such a variation has a stronger effect at the coast, where it is thinner. In terms of cave genesis, new caves can be formed over the older ones, thus producing a more complex, multistage network of karst voids. New vadose and phreatic conditions may develop in a function of the entity of the sea-level change. Cave elevations are related to prior sea-level highstands because caves often develop at the halocline or at the mixing zone between freshwater and salt water, in which oscillations occur in synchrony with the sea level in the coastal zone [39,42]. In the case of eogenetic carbonates, flank margin caves can be formed 
immediately after rock deposition, as syndepositional caves [43,44]. According to other authors, speleogenesis in coastal eogenetic limestones can be strongly controlled also by the distribution of carbon dioxide, with significant input by organic components $[45,46]$. Flank margin caves can also be found in telogenetic carbonates, linked to the presence of joints and fractures [47,48], marking the level of past sea-level highstands, which are nowadays also far from the coastline [49-51].

For what is stated above, eogenetic caves are, by far, the most common in coastal karst environments. However, this paper focuses on selected telogenetic carbonates of Sardinia and Murcia (Spain), where specific research on benthic foraminifera was performed. The unique environment of anchialine habitats, deriving from a mixed salinity water body for which preservation is contained by a rock mass [32], is common in coastal karsts, which are widespread in the Mediterranean, especially on the northern side (Figure 1). Nevertheless, it has to be mentioned that the highest distribution of known caves in the northern Mediterranean certainly also reflects a greater number of researches in this sector with respect to the southern coasts of the Mediterranean Basin. In such an environment, karst ecohydrology integrates landscape features with groundwater hydrology and freshwater biology [52]. Studying the organisms present in coastal caves [53-55] represents a unique opportunity to highlight species' wide variety and distribution [56-58] in the function of the most significant environmental parameters characterizing these transition areas between land and waters of different chemistry. Among these parameters, light attenuation is one of the most relevant [58,59]. Many studies in the cave environment concerning sponges, anthozoans, polychaetes, bryozoans, decapods, bivalves, and fishes [60] were carried out with little attention paid to benthic foraminifera $(\mathrm{BF})$. Despite the few studies considering this group, 106 species have been recognized in Mediterranean marine caves [60]. This review aims to analyze the available scientific literature on $\mathrm{BF}$ from marine caves to verify their effectiveness as paleoecological and ecological indicators.

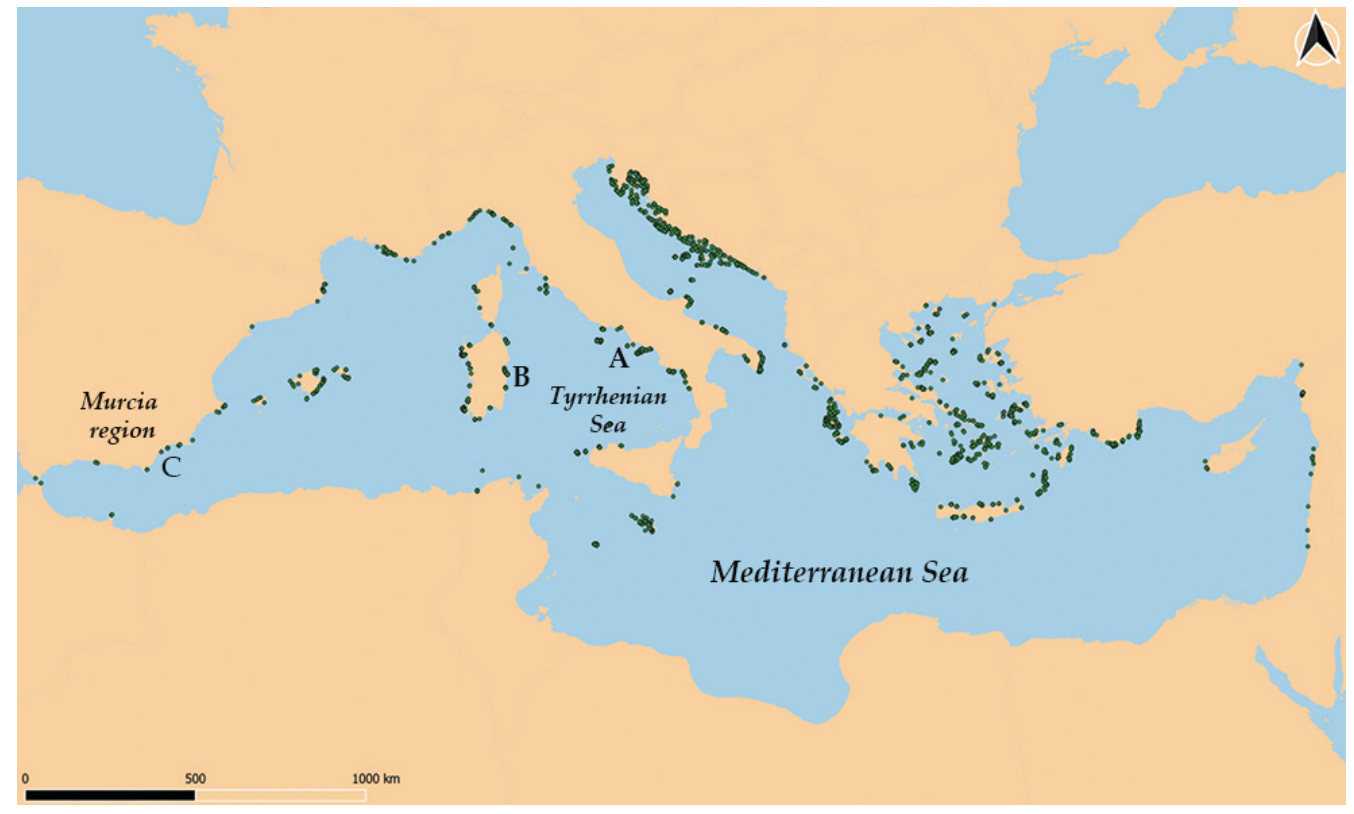

Figure 1. Distribution of known marine caves (green dots) in the Mediterranean Sea. (A) Isca cave (Tyrrhenian coast); (B) Bue Marino and Bel Torrente caves (Gulf of Orosei); (C) CT12 (Murcia region) (modified from [60]).

\subsection{Benthic Foraminifera as Ecological and Paleoecological Indicators}

Foraminifera are both planktic and benthic single-celled eukaryotic organisms (protists) with about 40,000 fossil and 10,000 living species on the whole [61,62]. About 4000 species of living benthic foraminifera (BF), mostly with a mineralized shell, have been described in ecological studies [63]. They inhabit a wide range of aquatic envi- 
ronments, from the transitional to the deep-sea [64,65], and are generally abundant in sediments, where they typically constitute well-diversified assemblages. In addition, they also live in environments that may be considered extreme because of the wide variability of one or more parameters (salinity, temperature, $\mathrm{pH}$, dissolved oxygen, nutrients, light, and contaminants) and may rapidly re-colonize the bottom sediment after disturbance events $[64,65]$. They are also susceptible to environmental changes because diversified assemblages offer a broad spectrum of potential responses. Their short life-cycle (a few months for most taxa) allows for the assemblages' total renewal, quickly adapting to the changing environment [66,67]. For this, surface sediment samples may contain many generations of dead specimens, corresponding to the average conditions, deprived of seasonal effects $[68,69]$. There are many techniques to distinguish living from dead foraminifera. The most used of these are based on vital functions of the foraminiferal cell and the staining of cytoplasm by biological solution [70,71].

Ecological indicators provide comprehensive and quantitative information of the state of ecosystems because they are linked through a causal relationship with the origin of environmental stress. They may be recognized at different hierarchic levels, from a single specimen to a whole community, ecosystem, or landscape. To be easily and reliably applied, ecological indicators should be based on sensitive, diverse, worldwide widespread, and abundant organisms. Benthic foraminifera are excellent environmental indicators because they have all of these characteristics. Moreover, their mineralized tests preserved in the sediments help recognize the changes of conditions through past times by studying subfossil assemblages from sediment cores and identifying the in-situ reference conditions [72-74]. Based on all these characteristics, in recent decades, BF have increasingly been used as a reliable proxy for the environmental characterization and monitoring of marine habitats and the assessment of the ecological status [75]. They are also suitable for marine caves characterized by physical gradients (light, oxygen, salinity, etc.), a decreasing pattern of nutrients supply, and decrease in species richness and biomass of benthic organisms [76].

\section{Reconstructing Paleoenvironments in the Present and Past Marine Caves}

The high potential preservation of foraminiferal tests allows for the recovery of fossil or subfossil assemblages bearing reliable and detailed environmental information, despite the possible taphonomic processes which might have modified the original ones [74]. Furthermore, in caves that are currently or in the past located close to the sea-level, foraminiferal assemblages record the long-term environmental changes linked to past climate and sealevel variations, tectonics, and extreme events, such as tsunamis and typhoons [77-85].

Corbridge cave (Berry Head, southwest England), formed in Devonian limestone during the Pleistocene and currently located between 5 and $10 \mathrm{~m}$ a.s.l., showed a bottom extensively covered by laminated mud. It was interpreted as a deposit of marine origin due to marine microfauna, such as ostracods, sponge spicules, echinoid spines, and other echinoderm skeletal elements. The most abundant foraminiferal fauna, constituted by shallow-water taxa like Ammonia beccarii and Lobatula lobatula, was found in the samples with the highest percentages of fine sand (up to $23 \%$ ). They were interpreted as displaced from a beach or the nearshore marine environment during storm events, providing evidence of the proximity of sea-level. Thanks to dating, these marine sediments were attributed to the marine isotopic stages (MIS) 7 and 5e, allowing for recognizing a paleo sea-level higher than the present one ( +7.2 and $+5.8 \mathrm{~m}$, respectively) during these warm periods [77].

The most ancient foraminifera typical of cave environments were found in the Late Pleistocene Rumena Cave (Sicily, Italy), currently located $100 \mathrm{~m}$ a.s.l. Two encrusting species, Cornuspiramia cfr. adherens and Planogypsina acervalis were associated with Scleractinian corals (Dendrophylliidae and Caryophylliidae), bryozoans, and serpulids. On the whole, the paleoecological significance of this community indicated a cave below the sealevel in the dark to semi-dark zone, which remained close to the sea level, and repeatedly 
flowed as a consequence of the interplay of vertical tectonic movements and the climatically driven sea-level fluctuations during the Late Quaternary period [78].

A cave on the northern coast of Sicily, currently located at $52 \mathrm{~m}$ a.s.l., contained a semi-dark cave association dominated by the dendrophylliid coral Astroides calycularis. Miniacina miniacea, a very large (up to $20 \mathrm{~mm}$ ) sessile foraminifer that may contribute up to $1 \%$ of the surface of the total biotic cover [60] was a component of this association which was interpreted as a warm community of Tyrrhenian age [79].

In a coastal cave in Aceh (Indonesia), sediments containing shallow-water benthic species (Ammonia spp., Elphidium spp.), mixed with planktonic ones (Globigerina sp.) of up to $14 \%$, transported by high energy events, were associated with tsunamis. Based on these results and radiocarbon dating, the authors recognized tsunamis events from 7400 yrs. BP to 2004 CE. Interpreting, on the whole, the stratigraphic sequence, they deduced that the recurrence time of tsunamis in the Indian Ocean is comprised between 450 and 2000 years and that long-dormant periods may follow the largest tsunamis, such as that of 2004 [80]. Like tsunamis, typhoons left a peculiar foraminiferal record in a coastal cave of the Salcedo coast (Philippines). The assemblages were constituted mainly by intertidal taxa (Amphistegina radiata, Baculogypsina sphaerulata, and Calcarina spp.) and abraded subtidal taxa (Peneroplis planatus). These results showed the potential of coastal caves to host wellpreserved archives of paleo storm deposits [81]. The hypothesis of tsunami deposits has also been advanced for sediments of a small Bermudian cave located at $21 \mathrm{~m}$ a.s.l. They contained a fossil foraminifera assemblage mainly constituted by brackish-water taxa (Polysaccammina ipohalina and Pseudothurammina limnetis). However, by comparison with assemblages from modern anchialine caves, it was finally deduced that they derived from a sea-level high stand at $21 \mathrm{~m}$ a.s.l. during MIS 11 [82].

The spatial and temporal changes of foraminiferal assemblages in cave environments allowed the reconstruction of environmental changes due to several factors. The distribution of larger BF was studied in dated sediment cores and surface sediments from the Daidokutsu Cave (Okinawa, Japan) using these symbiont-bearing organisms as proxies for light conditions. They reconstructed a decreasing trend that occurred about 5000 years ago. BP was attributable to the narrowing of the entrance for the progressive infilling of the cave [83].

Some studies recognized the spatial and temporal environmental changes related to sea-level variation in the Green Bay Cave (Bermuda). The facies analysis on 12 radiocarbondated sediment cores allowed for identification of the succession of distinct depositional environments with peculiar faunal content. Changes in BF assemblages marked the progressive flooding of caves, which occurred during the Holocene transgression, by identifying biofacies with different hydrogeological characteristics [84]. Other well-studied karst systems are in the Yucatan peninsula (Mexico), where surface sediment samples, collected along a transect in the Aktun Ha cave, were analyzed for dead BF (thanatocoenosis). Isotope ratios $\left(\delta^{13} \mathrm{C}\right.$ and $\left.\delta^{18} \mathrm{O}\right)$ from foraminifera shells were determined to reconstruct salinity variations during shell secretion. The results showed an abrupt transition from a freshwater assemblage, dominated by thecamoebians with rare Jadammina macrescens and Ammonia tepida, to a marine assemblage with Bolivina spp. and Elphidium sp. This faunal change was attributed to the flooding of the cave by marine waters during the Holocene sea-level rise [85]. A more recent study on the Aerolito Cave (Yucatan) analyzed the effects of changing terrestrial and marine contributions (water and organic matter) over time on the benthic foraminiferal assemblages from several sediment cores distributed along a gradient from terrestrial to marine conditions. The reduction of infaunal taxa and the increase of epifaunal clinging ones was interpreted as a response to the decrease in the organic matter supply due to the reduction of the mangrove areal extent in the last millennium. This result indicates that landscape changes can impact ecosystem functioning within adjacent subterranean habitats [86]. 


\section{Characterizing Present Environments in Marine Caves}

\subsection{General Overview on Recent Benthic Foraminifera from Worldwide Marine Caves}

Up to now, recent foraminifera in marine caves have been only occasionally studied. Most of these studies are concentrated on the Yucatan and Bermuda cave systems, where foraminiferal assemblages from surface sediment have been described since the early 2000s.

Surface sediment samples from the cenotes of the Yucatan peninsula, characterized by very low salinity (1.5-4.5 psu), revealed four low-diversity assemblages constituted by $\mathrm{BF}$ and thecamoebians corresponding to environments with different salinity values. Along the salinity gradient, the brackish-water agglutinated Jadammina macrescens was first recorded, associated with freshwater thecamoebians, while, at the highest salinity, Ammonia tepida and Elphidium sp. were found. The transition from a thecamoebian-dominated to a foraminiferan-dominated assemblage occurred at a salinity of approximately $3.5 \mathrm{psu}$ [87].

A first paper, aimed at illustrating modern foraminiferal species from Bermuda, reported a list of foraminifera from caves, including typical taxa of marginal marine environments, shelf and deep-sea, such as Ammodiscus tenuis, Rosalina spp., and Cibicides refulgens, respectively [88]. Successively, BF from surface sediment samples of the Green Bay cave system were analyzed to investigate foraminiferal ecology concerning habitat variability. Based on foraminiferal data, the authors recognized two environments, the terrestrially-dominated (anchialine) and the marine-dominated, and were each divided into distinct habitats consistent with the local hydrogeology and sedimentology. Typical marsh species were found in the first environment, corresponding to the brackish meteoric lens, while marine taxa (Rosalina and Bolivina) were present in the second one, below the halocline. In the marine environment Quinqueloculina spp. dominated the assemblage at the entrance, while, depending on more or less effective water circulation, Spirillina vivipara or Spirophthalmidium emaciatum were the most abundant species [29]. Other Bermudian caves (Deep Blue and Cow Cave) were studied to recognize the response of shallow-water benthic foraminifera to water level variability from tidal forcing and the source of organic carbon. The intertidal assemblage, with the brackish-water Trochammina inflata, was primarily controlled by tidal exposure. The subtidal-terrestrial and subtidal-marine assemblages were more conditioned by the sediment texture and organic carbon amount and source. The first one was dominated by the infaunal Bolivina variabilis and Melonis barleeanus, while in the second one, the epifaunal S. emaciatum and Sigmoilina tenuis, prevailed. These last species were considered to be emerging indicators of subtidal habitats flooded by an oxygenated saline groundwater mass of coastal karst aquifers in tropical and subtropical settings [89]. Finally, another paper considered several Bermudian caves, including those of the earlier studies, to analyze the response of $\mathrm{BF}$ to tidal exposure and sediment parameters (sediment grain size, bulk organic matter, total organic carbon, $\mathrm{C} / \mathrm{N}$, and $\delta^{13} \mathrm{C}$ ). The results confirmed the earlier findings, better characterizing the foraminiferal assemblages in relation to the organic matter source, recognized as one of the main factors influencing foraminiferal distribution [90].

\subsection{The Mediterranean Caves}

Caves may be found in many geological settings, produced by different processes, as stated in § 1.1; however, the most common are these are formed by karst phenomena on carbonate rocks. Many sectors with coastal carbonate cliffs characterize the Mediterranean coast, and because of this, the region is rich in marine caves, mostly documented so far on the northern side (Figure 1) [91]. They have been extensively and mainly studied by geologists and speleologists [2,6,7], but also by biologists [92,93], mainly because these environments host rich sessile macrobenthic fauna on their walls and ceilings [60].

Benthic foraminifera from Mediterranean marine caves have been occasionally reported since the 1980s, mostly in studies focused on hard-bottom macrobenthic communities. Due to the sampling methods, aimed at detecting macrobenthic organisms with real or photographic samples, the only foraminiferal species commonly recognized was M. miniacea. It has been found in several Mediterranean marine caves, both in the eastern 
and western Mediterranean, often at the entrance, but also in the semi-dark and dark zones [94-97]. It was also recognized, together with macrobenthic taxa, as constituting the fouling encrusting statues and marble fragments recovered from the Grotta Azzurra (Capri, Italy) [98] and as part of bioconstructions [99]. In few cases, other foraminiferal taxa were described as contributors to bioconstruction. An in-situ experiment focused on the development of sessile fauna in a marine cave of the Ionian Sea recorded the presence of benthic foraminifera, identified at a family (Nubeculariidae) or superfamily level (Rotaliacea), among bioconstructors [100]. More recently, another species, Cornuspiramia adherens, was reported as encrusting nodular bryozoan concretions in two marine caves of the Aegean Sea [101].

An early paper specifically focused on the study of foraminiferal assemblages considered the biocoenosis from the walls and bio- and thanatocoenosis from the bottom sediment of the Isca cave (Tyrrhenian Sea, Italy). Results of the quantitative analysis showed the dominance of $M$. miniacea (87\%) in the biocoenosis of the cave walls. At the same time, the other five species were rare, among which the typically infaunal, deep-water species Melonis barleeanus was recognized. Furthermore, only the agglutinated Rhizammina sp. was found living in the sediment, despite a diversified dead assemblage with dominant M. miniacea and abundant Miliolida (Quinqueloculina spp. and Adelosina spp.). Considering that nearly all of the species found in the thanatocoenosis may live by clinging to hard substrates, and considering the low number of samples in relation with the foraminiferal density on the walls, the author concluded that all species found were dead in the sediment, except for Rhizammina and Textularia, which were derived from the walls [102].

\subsubsection{Studies Carried out in the Gulf of Orosei (Italy)}

Since 2014, a research project aimed at investigating the potential use of BF as an ecological indicator in Mediterranean marine caves has been carried out thanks to the synergic cooperation between cave divers of Global Underwater Explorers (GUE) and researchers of ISPRA (Institute for Environmental Protection and Research). The study was of particular importance because there was no previous record of living assemblages in sediments from marine caves of temperate seas.

The research project started in the Gulf of Orosei (Sardinia, Italy), a coastal karst area that extends for more than $37 \mathrm{~km}$ with cliffs directly on the sea. Mesozoic dolostone and limestone, affected by extensive karst phenomena, overlie a Paleozoic Variscan basement composed of granites and phyllites. Karst landforms, such as dolines and dry canyons called "codula" which are active only during heavy rainfall, characterize the landscape.

Many caves, formed by the wave action on joints and structurally weaker areas, are located along the coast extending for many kilometers in correspondence with the freshwater outlets of the karst systems (Figure 2) [103].

In two of these caves, Bel Torrente (BT) and Bue Marino (BM), after a survey of the cave, 15 sampling stations (Figure 3) were positioned in 2014-2015 from the entrance to the inner section along a line at $30 \mathrm{~m}$ distance and monitored once every year in the period 2014-2016. In particular, BM was first studied for the North Branch, extending the sampling towards the inner sector in the 2016 campaign; Middle Branch was also included in the study in the same year. Sediment samples have been collected and analyzed at each station for grain size and benthic foraminifera, while a multiparameter probe has measured water parameters.

The BT cave has a total development of $8.6 \mathrm{~km}$ even if it is still being explored [104]; it is constituted in the first sector by a main conduit, wide from 5 to $20 \mathrm{~m}$, which develops close to the sea-level for the first $600 \mathrm{~m}$ (Figure 3) reaching a $50 \mathrm{~m}$ depth in the inner one. It drains waters from the karst canyon of Codula Sisine and has a widely variable flow rate, ranging from 100 to $1000 \mathrm{~L} \mathrm{~s}^{-1}$ during overflow periods and $10 \mathrm{~L} \mathrm{~s}^{-1}$ during dry conditions. After heavy rains, the tunnel is entirely flooded by freshwater with flow of up to $2 \mathrm{~m} \mathrm{~s}^{-1}$, while during dry periods, marine water is overlain by freshwater forming a mixing zone, known as halocline $[105,106]$. 


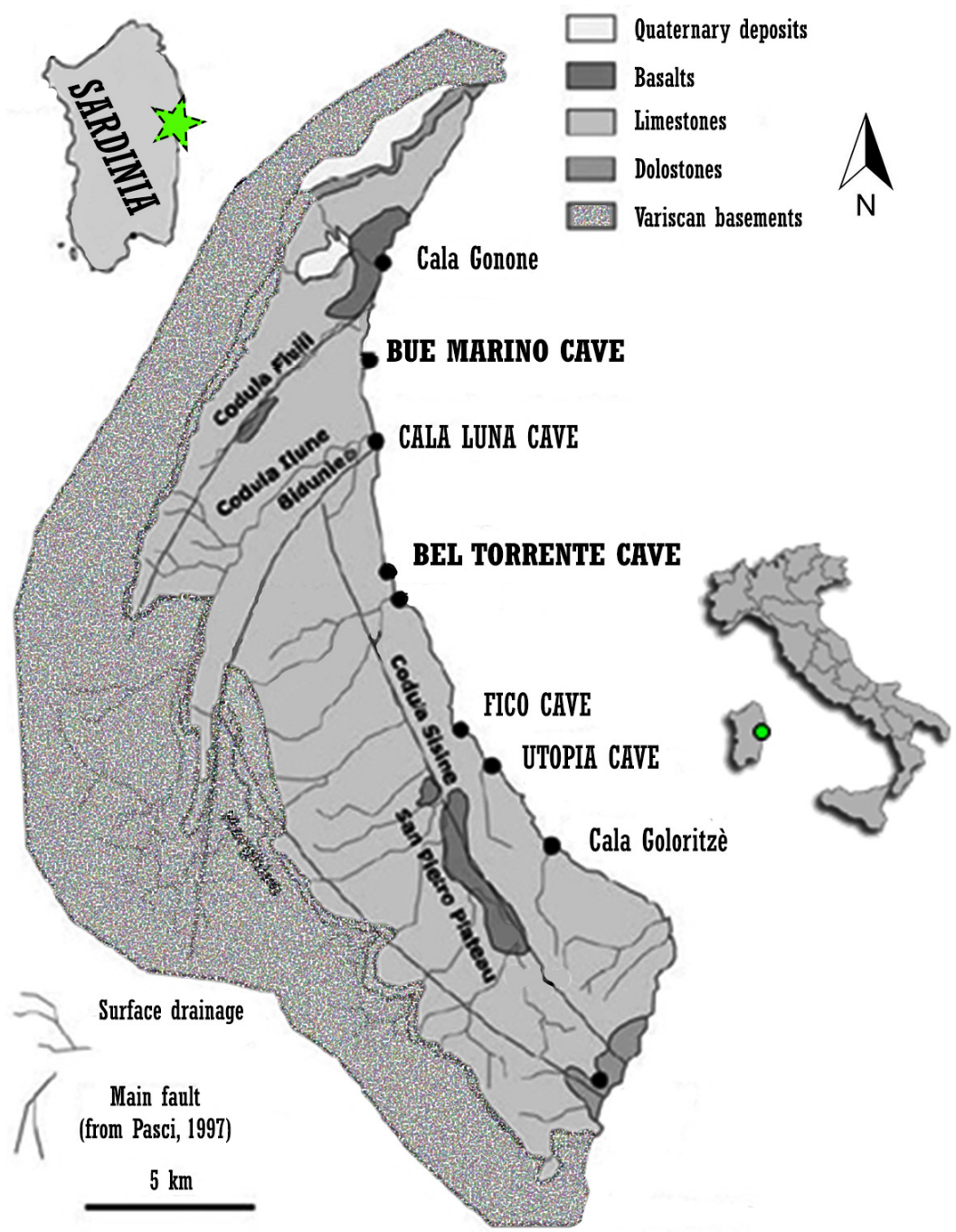

Figure 2. Geological scheme of the Gulf of Orosei with the location of the marine caves (modified from [103]).

The BM cave is an extensive cave system constituted by three branches, the North, Middle, and South Branch, which develops for over $70 \mathrm{~km}$ (Figure 3). The North Branch is characterized by a large conduit that drains water from the Codula Fuili recharge area with a base flow of $40 \mathrm{~L} \mathrm{~s}^{-1}$ and discharges large volumes of freshwater $\left(>1 \mathrm{~m}^{3} \mathrm{~s}^{-1}\right)$ during periods of flooding. When the base flow is prevalent, sea water penetrates for $1500 \mathrm{~m}$ into the branch. The Middle Branch is the least impressive in dimension and is probably linked to smaller sinks in the Codula Ilune riverbed. Finally, the South Branch has the largest conduit and a very low base flow (a few liters per second), even though it carries large volumes of freshwater originating in the Codula Ilune canyon during heavy rainfall $[105,107,108]$.

In both caves, mainly sandy sediments were recorded, with some gravelly sands or sandy gravels. Sediment was mainly constituted by coarse, or very coarse, mineral grains, quartz, plagioclases, k-feldspars, biotite, volcanic lithic fragments, or rare schists, while the organic fraction was scarce. Pelitic sediment enriched in vegetal debris was recognized only in the BM cave, in station 6, located at the confluence of the North and Middle branches. Sediment composition testifies that the Variscan basement, outcropping some kilometers from the coast, acts as a main sedimentary source (Figure 2). In the BM cave, the peculiar sediment texture recognized at station 6 and the high organic content indicate a supply from the Middle Branch $[105,106]$. 




Figure 3. Sampling map of Bel Torrente (BT) from and Bue Marino (BM) caves, Sardinia, Italy [103].

The sampling carried out in 15 stations in each cave in summer 2014 revealed BF's presence in both caves, although with an absolute abundance at most of few specimens per gram of dry sediment in most samples; however, the main taxa were found both as dead and living (rose Bengal stained) in the sediment. While in the BM cave, BF were found in all 15 stations, in the BT cave they were recovered up to station 11 (Figure 3). The succession of three foraminiferal assemblages, corresponding to three different ecozones, was recognized in both caves (Table 1), although to a different extent $[105,106]$ and references therein:

- A marine ecozone, located immediately close to the entrance, was exclusively characterized by taxa with carbonate test (porcelaneous or hyaline). Typical shallow-water symbiont-bearing species, such as Peneroplis pertusus, P. planatus, and Elphidium crispum, prevailed in the assemblage and were exclusive to this ecozone. Because these species are common in the shallow-water assemblages of the Sardinian coast, this assemblage indicates environmental conditions very similar to those that are normally marine.

- The entrance ecozone started within the first $90 \mathrm{~m}$, in correspondence of BT4 and BM4. Hyaline taxa generally prevailed, but the agglutinated ones were also rather abundant. The dominant species, the hyaline Gavelinopsis praegeri and Rosalina bradyi, are epifaunal taxa that may be attached to phytal substrates or mineral grains. The first one is possibly living in a wide bathymetric range of the continental shelf. The hyaline infaunal B. variabilis accompanied them, and the agglutinated Reophax dentaliniformis was also abundant. It is an infaunal species common in the Baltic Sea and Norwegian fjords, recognized as a successful opportunistic species in re-colonizing disturbed habitats.

- The transitional ecozone started at 120 and $300 \mathrm{~m}$ from the entrance in correspondence of BT6 and BM11, respectively. The innermost foraminiferal assemblage characterized it, mainly constituted by agglutinated taxa. Eggerelloides advenus, Lepidodeuterammina ochracea, and $R$. dentaliniformis were the most common species. Eggerelloides advenus is an infaunal species typical of high latitude basins which tolerates low-salinity conditions, and is considered to be a stress-tolerant opportunistic species. Lepidodeuter- 
ammina ochracea is an epifaunal clinging species that is typical of cold waters and adapted to live on the coarse sand of high-energy cold waters. Station BM6, although included in this ecozone due to the prevalence of E. advenus, showed peculiar features in terms of the low species diversity and high dominance of the main species. In this case, E. advenus showed an opportunistic behavior due to the abundant vegetal debris present in the sediment. This species is known to be opportunistic, being able to benefit from the abundant refractory organic material.

Table 1. Mediterranean caves with the main features of foraminiferal ecozones.

\begin{tabular}{|c|c|c|c|}
\hline & Bel Torrente & Bue Marino & CT12 \\
\hline & \multicolumn{3}{|c|}{ General features } \\
\hline Cave origin and characters & $\begin{array}{l}\text { karst; Anchialine cave, with } \\
\text { development strongly favored } \\
\text { by hyperkarst processes } \\
\text { (freshwater-saltwater mixing) }\end{array}$ & $\begin{array}{l}\text { karst; Anchialine cave, with } \\
\text { development strongly favored } \\
\text { by hyperkarst processes } \\
\text { (freshwater-saltwater mixing); } \\
\text { three main branches }\end{array}$ & $\begin{array}{l}\text { hypogenic origin; } \\
\text { submarine cave }\end{array}$ \\
\hline \multirow[t]{2}{*}{ Sediments } & $\begin{array}{c}\text { coarse grain size, terrigenous, } \\
\text { terrestrial origin }\end{array}$ & $\begin{array}{l}\text { coarse grain size, terrigenous, } \\
\text { terrestrial origin; abundant } \\
\text { vegetal debris in the } \\
\text { Middle Branch }\end{array}$ & $\begin{array}{l}\text { fine grain size, authigenic } \\
\text { micrite, bioclasts }\end{array}$ \\
\hline & \multicolumn{3}{|c|}{ Foraminiferal ecozones } \\
\hline Marine ecozone & $\begin{array}{l}\text { low-mild absolute abundance, } \\
\text { high diversity; P. pertusus, E. } \\
\text { crispum, L. lobatula, G. praegeri }\end{array}$ & $\begin{array}{l}\text { low absolute abundance, mild } \\
\text { diversity; P. pertusus, G. praegeri, } \\
\text { E. crispum, L. lobatula }\end{array}$ & $\begin{array}{c}\text { high absolute abundance, } \\
\text { mild diversity; } M \text {. subrotunda, } \\
\text { L. lobatula, G. praegeri }\end{array}$ \\
\hline Entrance Ecozone & $\begin{array}{l}\text { low absolute abundance, mild } \\
\text { diversity; prevalence of } \\
\text { calcareous taxa (G. praegeri, } \\
\text { Bolivina spp., Quinqueloculina } \\
\text { spp.) over the agglutinated (R. } \\
\text { dentaliniformis) }\end{array}$ & $\begin{array}{l}\text { low-mild absolute abundance, } \\
\text { mild-high diversity; prevalence } \\
\text { of calcareous taxa (G. praegeri } \\
\text { and } R . \text { bradyi) over the } \\
\text { agglutinated ( } \text {. dentaliniformis) }\end{array}$ & $\begin{array}{l}\text { high absolute abundance, } \\
\text { low-mild diversity; } P \text {. } \\
\text { corrugata and S. vivipara with } \\
\text { similar percentages, } T \text {. } \\
\text { inornata. Increase of epifaunal } \\
\text { clinging/attached taxa }\end{array}$ \\
\hline Transitional ecozone & $\begin{array}{l}\text { low absolute abundance, } \\
\text { low-mild diversity; } \\
\text { prevalence of agglutinated } \\
\text { taxa (E. advenus, } R \text {. } \\
\text { dentaliniformis, C. jeffreysii) } \\
\text { over the calcareous ones }(G \text {. } \\
\text { praegeri, } R \text {. brady, A. inflata) }\end{array}$ & $\begin{array}{l}\text { low absolute abundance, mild } \\
\text { diversity; prevalence of } \\
\text { agglutinated taxa (E. advenus, L. } \\
\text { ochracea, R. dentaliniformis, C. } \\
\text { jeffreysii) over the calcareous } \\
\text { ones (G. praegeri, R. brady) }\end{array}$ & $\begin{array}{l}\text { high absolute abundance, } \\
\text { low-mild diversity; dominant } \\
\text { P. corrugata. Further increase } \\
\text { of epifaunal } \\
\text { clinging/attached taxa }\end{array}$ \\
\hline Confluence ecozone & not present & $\begin{array}{c}\text { high absolute abundance, } \\
\text { low-mild diversity; dominant } \\
\text { opportunistic agglutinated taxa } \\
\text { (N. polymorphinoides in spring, E. } \\
\text { advenus in summer) }\end{array}$ & not present \\
\hline $\begin{array}{l}\text { Beginning of the } \\
\text { barren zone }\end{array}$ & $\begin{array}{c}\text { at about } 330 \mathrm{~m} \text { from } \\
\text { the entrance }\end{array}$ & $\begin{array}{l}\text { at about } 450 \mathrm{~m} \text { from } \\
\text { the entrance }\end{array}$ & $\begin{array}{c}\text { barren zone not present } \\
\text { within the } 120 \mathrm{~m} \text { length of } \\
\text { the cave }\end{array}$ \\
\hline $\begin{array}{l}\text { Driving environmental } \\
\text { factors of } \\
\text { foraminiferal zonation }\end{array}$ & $\begin{array}{l}\text { salinity and pH gradient, } \\
\text { environmental instability due } \\
\text { to seasonal freshwater flows }\end{array}$ & $\begin{array}{l}\text { salinity and pH gradient, } \\
\text { environmental instability due to } \\
\text { seasonal freshwater flows; } \\
\text { organic matter in the } \\
\text { Middle Branch }\end{array}$ & $\begin{array}{l}\text { sediment grain size, } \\
\text { organic matter }\end{array}$ \\
\hline
\end{tabular}

Identifying the same ecozones in the two caves testifies that BF are suitable proxies of habitat partitioning in cave environments. Except for the marine ecozone, caves are inhabited by peculiar assemblages which are well-distinct from those of marine shallowwater of the same area. In particular, abundant agglutinated taxa are uncommon in 
shallow-water foraminiferal assemblages of the Mediterranean Sea. Overall, the succession of ecozones was not attributed to a single parameter but a comprehensive environmental gradient determining increasing stress due to the decrease of marine influence. Based on the ecological meaning of foraminiferal assemblages, the environmental stress was attributed to high seasonal variability and high water energy. According to different cave morphology, the prevalence of agglutinated taxa starting from 100-300 m from the entrance was probably due to an adaptation to highly variable conditions regarding carbonate availability, which was strongly influenced by the decrease in salinity and $\mathrm{pH}$, and mostly conditioned hyaline and porcelaneous taxa. Moreover, because the agglutinated taxa are not present in typical shallow-water assemblages of the Sardinian coast [109-112], a very effective dispersal as propagules (juvenile specimens, $<32 \mu \mathrm{m}$, in a cryptic stage) may be supposed for these taxa $([105,106]$ and references therein).

The results of the 2015 sampling campaign, carried out during spring time, after the end of the rainy season, provided additional information on the seasonal variability of environmental conditions in the two caves, especially when compared with the results of summer 2014 [103]. In the BT cave, living and dead foraminifera were extremely scarce, with 35 living specimens in the 15 stations. This great depletion of foraminifera may not have resulted from prohibitive water parameters ( $\mathrm{T}, \mathrm{Sal}, \mathrm{pH}$, and $\mathrm{DO}$ ) at the sampling time because they were in an ideal range for the life of BF. The disappearance of living and dead foraminifera let us suppose that they were mostly displaced and/or destroyed by strong freshwater flows during the rainy season, which caused the surface sediment layer to be removed. The few living specimens represented the beginning of the re-colonization, but no ecological zonation was possible. The reduction of foraminiferal abundance was less evident in the BM cave, demonstrating that the intensity of water flow during the winter was lower than in the BT cave. The ecozones identified in the summer of 2014 were also recognized in the next spring, with the same faunal characteristics but to a different extent, due to the development of a new ecozone in three stations (BT4-BT6) with abundant vegetal debris near the intersection of the North and Middle branches (Table 1). The confluence ecozone was characterized by a foraminiferal assemblage with high absolute abundance (FN: 1853-6267) and mild diversity ( $\alpha$ index: 10.9-13.7), dominated by Nouria polymorphinoides, a very fragile agglutinated species, in association with G. praegeri and Bolivina spp. It is a shallow-infaunal taxon that does not tolerate oxygen depletion. Such a foraminiferal assemblage corresponded to sediment with a higher pelitic fraction and waters with higher salinity, temperature, $\mathrm{pH}$, and dissolved oxygen. The assemblage structure in the confluence ecozone is the same as that which was recognized in BM6 in the previous summer, although the dominant species was E. advenus. It has been supposed that $N$. polymorphinoides is an early colonizer of the confluence ecozone during spring, benefiting from the abundant fresh organic matter supplied by the Middle Branch, when there is still high oxygen levels. In summer, the influence of the Middle Branch on the Northern one is reduced to station BM6, and N. polymorphinoides is substituted by E. advenus, which tolerates the low-oxygen conditions and uses refractory organic matter. The faunal shift from the hyaline-dominated assemblage of the entrance ecozone to the agglutinated assemblage of the transitional ecozone was attributed to the negative salinity and $\mathrm{pH}$ gradients. Small changes in $\mathrm{pH}$ (0.1 unit) and salinity could have consequences on benthic foraminiferal assemblages in terms of survival rate, reproduction, calcification, and resistance to shell dissolution ([103] and references therein).

The summer 2016 sampling was only focused on the BM cave where, based on earlier studies, foraminifera showed a wider distribution and recorded diversified environments attributable to different contributions. For this, the new sampling also included four stations of the Middle Branch, while sampling in the North Branch was expanded to the innermost sector (Figure 4) [113]. 


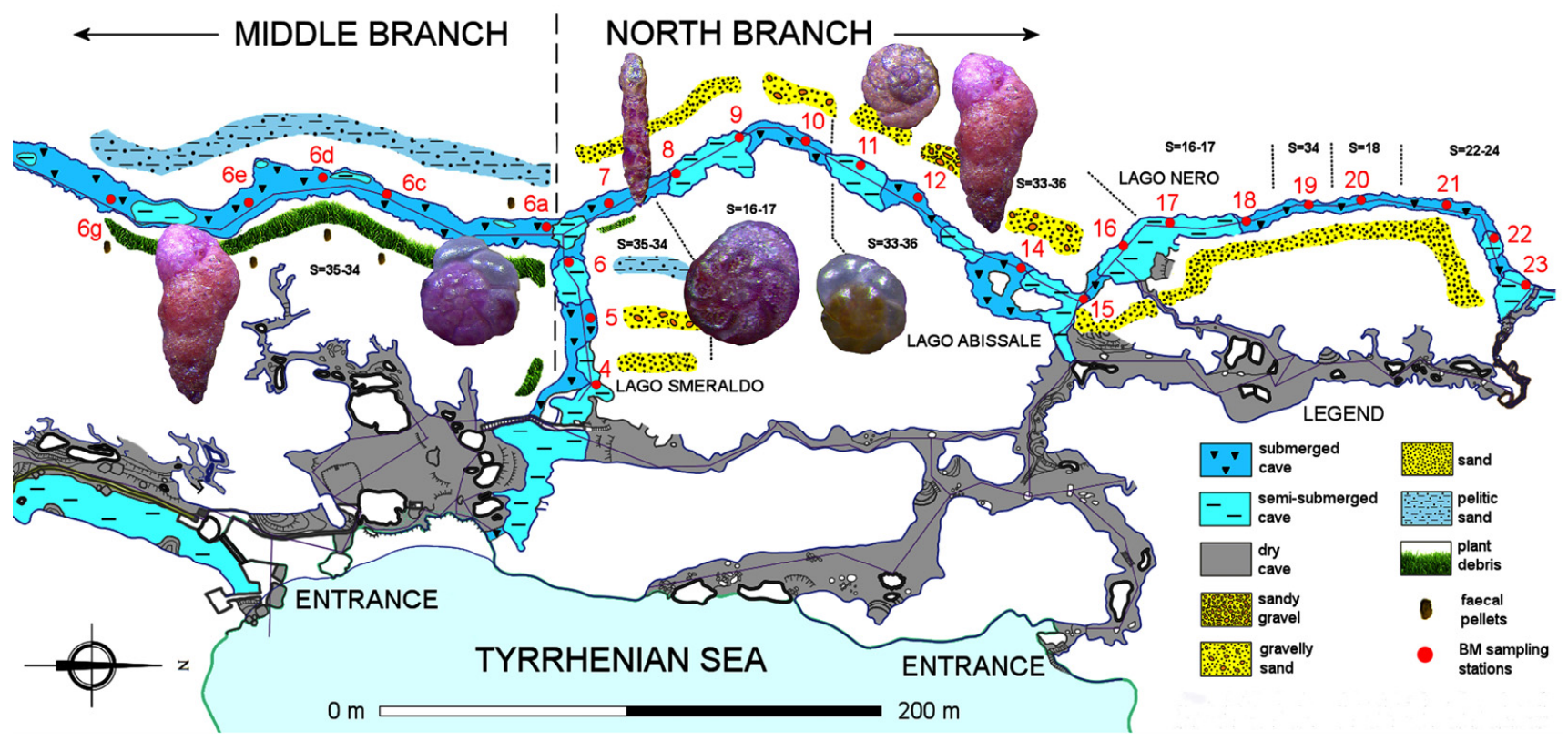

Figure 4. Different biotic and abiotic characteristics of the North and Middle Branches of the Bue Marino Cave. Sediment classification according to modified Shepard and specific constituents (plant debris, fecal pellets) of the cave sediments. Also salinity (S) is reported. The main species of the North and Middle Branches are illustrated. North Branch: Gavelinopsis praegeri, Rosalina bradyi, Eggerelloides advenus (up to 23\%), Reophax dentaliniformis, and Lepidodeuterammina ochracea. Middle branch: Eggerelloides advenus (up to 84\%) and Ammonia tepida (modified from [113]).

Based on the foraminiferal and grain size data and water parameter values, two main environments were identified. A well-oxygenated, less saline environment with coarse bottom sediment, correlated with a mixed calcareous-agglutinated assemblage (G. praegeri, Rosalina spp., E. advenus, and Reophax dentaliniformis) with high species diversity and low foraminiferal density, was recognized for the North Branch. In contrast, the Middle Branch revealed a scarcely oxygenated, more saline environment with fine bottom sediment enriched in vegetal debris; this was related to a prevalently agglutinated assemblage characterized by low species diversity and high foraminiferal density, with a high dominance of E. advenus (up to $83.6 \%$ ) associated to $A$. tepida. These two environments corresponded to the entrance and confluence ecozones of the previous studies, respectively. Therefore, they were interpreted as the result of water masses with different salinity, sediment, and organic matter contributions from the karst system in the two branches.

\subsubsection{Studies Carried out in the Murcia Region (Spain)}

Another Mediterranean area for the study of BF from marine caves was the coast of the Murcia region, close to Cabo Tiñoso (south-eastern Spain). From a geological viewpoint, this area is characterized by two overlapping tectonic complexes of the Betic Cordillera. The older one, consisting of mica-schist, quartzite, gneiss, and marble, constitutes the Paleozoic basement; the other is primarily composed of Mesozoic limestones and dolostones forming imposing cliffs along the coast. In addition, due to extensive karst phenomena, numerous caves of various dimensions and settings have developed, significantly controlled by tectonics ([114] and references therein).

The CT12 cave is of hypogenic origin $[115,116]$, with two marine entrances positioned at water depths of $12 \mathrm{~m}$ and $23 \mathrm{~m}$, converging in a unique conduit after a few meters (Figure 5). The cave then develops in a narrow conduit, with a large chamber at the end, for the total development of about $120 \mathrm{~m}$. Sediment samples were collected at seven stations starting from the convergence point of the two entrances and ending close to the wall of the final chamber. Samples were analyzed for grain size and BF. In addition, the brachiopod 
thanatocoenosis was also considered. This was the first study that compared the BF and brachiopods' response to the changing environment inside a marine cave. Sediment in the cave was mainly fine (clayey or sandy silt) with some coarser components locally. The fine fraction was constituted by authigenic micrite, while the coarser fraction consisted of bioclasts from organisms living on both the walls and the cave ceiling.

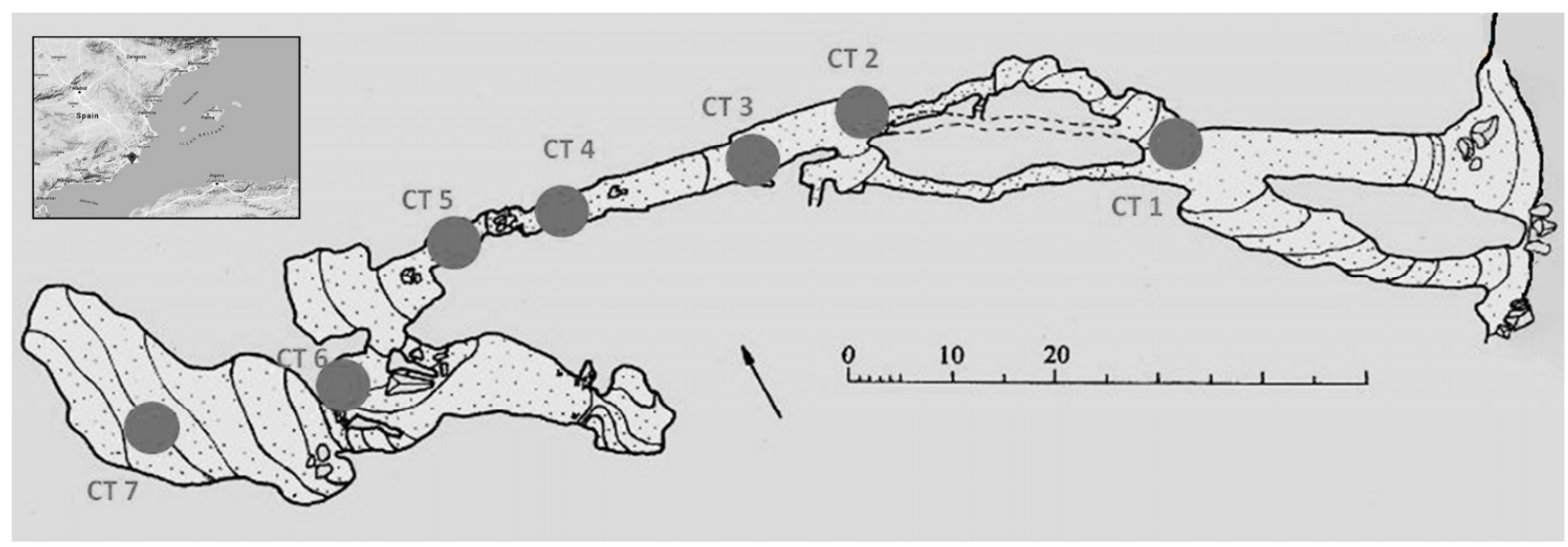

Figure 5. Location and sampling map of CT12 cave, Murcia region, Spain [114].

BF were abundant in the cave (some thousand specimens per gram of dry sediment), without a distinct pattern through the cave. On the whole, species diversity was high, with 100 identified species, and showed a pattern inversely correlated to the distance from the entrance. The statistical analysis recognized three foraminiferal assemblages corresponding to three ecozones. In the sample collected close to the entrance, G. praegeri, Miliolinella subrotunda, and Cibicidoides lobatulus prevailed (Figure 6, Table 1). The four samples collected along the conduit showed similar percentages of the two dominant species, Patellina corrugata and S. vivipara, at 15-23\%, while Tubinella inornata was significantly lower (6-18\%). In the two samples collected in the final chamber, P. corrugata became the dominant species, while S. vivipara and T. inornata were less abundant. The first two species live clinging to hard substrates, such as rocks, large mineral grains, bioclasts, or wood fragments, while the last one lives attached to hard substrates by an organic cement at the base of the proloculus ([114] and references therein). Spirophthalmidium emaciatum, indicative of oxic oligotrophic marine waters in Bermudian caves, was common in the CT12 cave.

Overall, the relative abundance of epifaunal clinging-attached foraminifera increased from the outer to the inner cave, representing an increasing degree of separation from marine conditions. Because the foraminiferal ecozones well corresponded to the cave morphology over small distances, the results of this study demonstrated the high sensitivity of these organisms to small-scale changes of cave habitat. Furthermore, the increase of epifaunal clinging-attached foraminifera corresponded to the increase of typical brachiopods of the cave environment [117].

Considering both BF and brachiopods, it was deduced that, despite the different lifestyles of these two groups, the strict correlation of environmental factors (i.e., light, nutrients, sediment texture, water parameters) changing along the cave determined an environmental gradient, which caused an increase in environmental stress that had similar effects on the different taxonomic groups. 


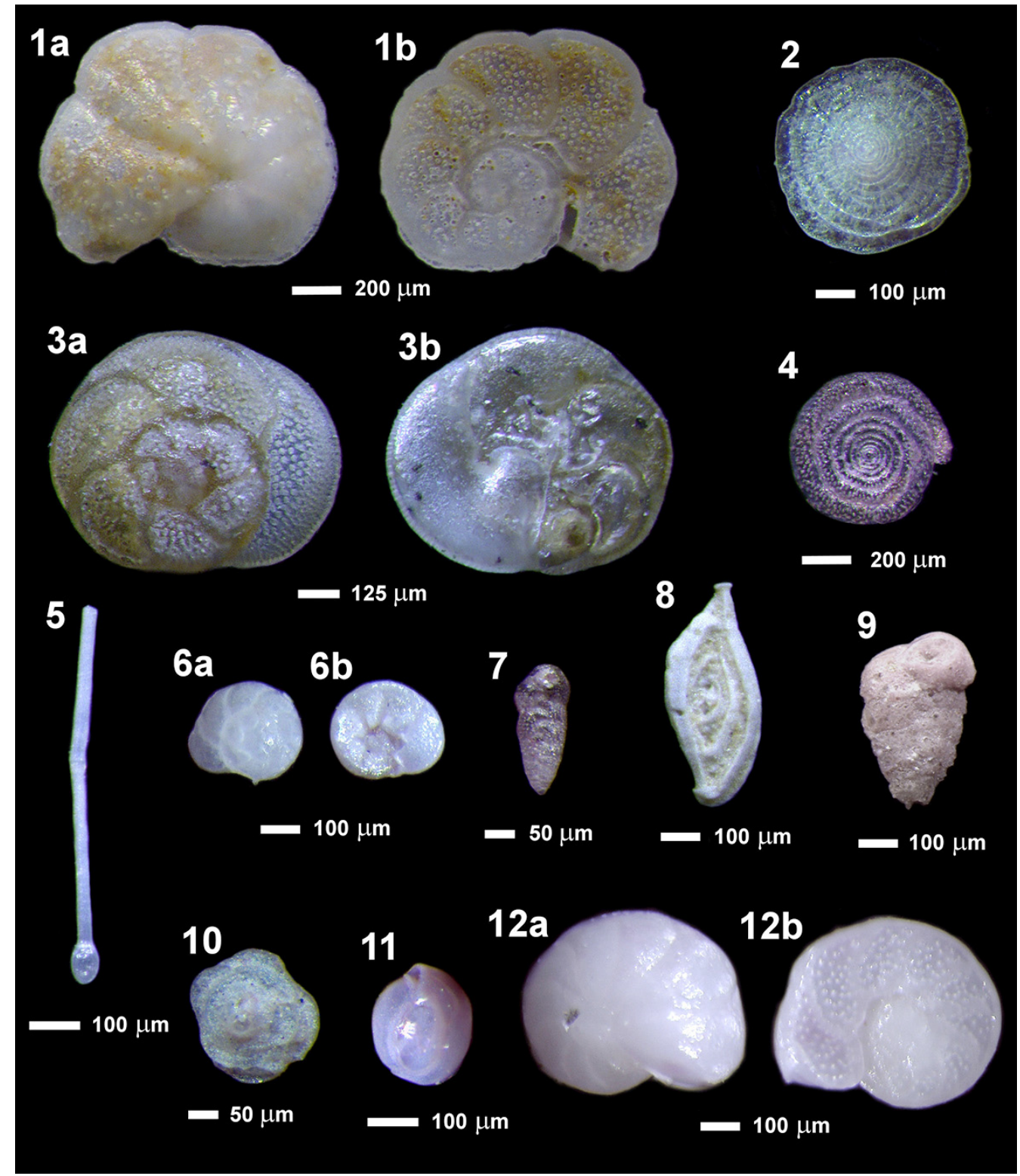

Figure 6. Commonly occurring Benthic Foraminifera in the CT12 cave: (1) Cibicidoides lobatulus, ventral view (a), dorsal view (b); (2) Patellina corrugata, dorsal view; (3) Rosalina bradyi, dorsal view (a), ventral view (b); (4) Spirillina vivipara; (5) Tubinella inornata, lateral view; (6) Gavelinopsis praegeri, dorsal view (a), ventral view (b); (7) Bolivina variabilis, lateral view; (8) Spirophthalmidium emaciatum, lateral view; (9) Textularia bocki, lateral view; (10) Sejunctella sp., dorsal view; (11) Miliolinella subrotunda, lateral view; (12) Cibicides refulgens, ventral view (a), dorsal view (b) [114].

\section{Lessons Learned from Foraminiferal Studies in Marine Caves}

Considering, on the whole, the studies concerning BF from marine caves, their reliability as paleoenvironmental and environmental proxies, already known for other betterstudied environments, is confirmed. This character is particularly important because marine caves are deeply influenced by the changing interaction between marine and terrestrial domains and preserve a record of environmental changes.

The study of fossil foraminifera in caves currently above sea level helps to reconstruct relative sea-level changes due to the interaction between eustasy and local tectonics during the Quaternary. Moreover, by analyzing fossil or subfossil foraminiferal assemblages in sediment cores, the recurrence of extreme events, such as tsunamis and exceptional storms, may be recognized. Furthermore, changes in light conditions may be reconstructed through 
the variable abundance of symbiont-bearing larger BF. Additionally, changes through time in the nutrient supply attributable to a change of the terrestrial landscape may be recognized from the ecological meaning of different assemblages.

In the reported studies on recent foraminifera of a soft bottom, the assemblages allowed us to recognize a succession of ecozones in wide cave systems and small marine caves, demonstrating excellent tools for habitat partitioning in marine caves. Common features of these ecozones were foraminiferal assemblages becoming less diverse and increasingly different from the typical marine ones, and moving away from the cave entrance. Furthermore, the faunal change was different according to different factors acting as environmental drivers; in caves affected by continental (freshwater, sediment, and organic matter) supply, such as Bel Torrente and Bue Marino, but also the Bermudian ones, the faunal shift from calcareous to agglutinated assemblage was interpreted as the response to a comprehensive environmental gradient of decreasing salinity and $\mathrm{pH}$, but also environmental instability due to seasonal freshwater flows [103,105,106,113] (Table 1). Overall, this gradient determined that increasing environmental stress more favorable to the stress-tolerant agglutinated taxa, particularly E. advenus [118]. On the other hand, in smaller caves with exclusive marine contributions, such as CT12, the faunal response to increasing enclosed conditions with increasing distance from the entrance was the considerable increase in epifaunal clinging/attached taxa to bioclasts, with the dominance of a single species, while absolute abundance remained high (Table 1). This faunal change was interpreted as the response to increasing nutrient availability associated with the more abundant fine sediment fractions [114].

On the whole, studies considered in this review indicated the high sensitivity of BF to respond to changing conditions along the environmental gradient developing a succession of assemblages corresponding to different ecozones. Their ecological significance provides information on the origin of terrestrial and marine contributions, while their yearly monitoring provides information concerning seasonal and short-term climatic variability. These caves are also natural laboratories for predicting future changes in marine systems. In particular, studying the environmental drivers determining the faunal shift from prevailingly-calcareous (G. praegeri, R. bradyi) to prevailingly-agglutinated (E. advenus, $R$. dentaliniformis) assemblages and the total disappearance of BF at an increasing distance from the cave entrance may provide information on global changes, such as ocean acidification. The possible disappearance of calcareous BF as a response to this phenomenon has many implications due to the importance of these organisms for $\mathrm{CO}_{2}$ sequestration in the carbon biogeochemical cycle and as contributors of carbonate sediments [64,119]. Further, studying small caves that are entirely flooded by marine waters has scientific value because BF demonstrated the capability of habitat partitioning at a small scale, implying that these environments constitute reservoirs of high diversity despite the small size.

Regarding the distribution of species, it has been pointed out that M. miniacea is the most widespread hard-bottom foraminifer in the Mediterranean region. Concerning sediment colonizer taxa, some similarities between the assemblage of the transitional ecozone of the CT12 cave and the Bermudian subtidal marine one, are recognizable for the abundance of $S$. vivipara and S. emaciatum (Table 2). Another common species in the caves of Sardinia, Spain, and Bermuda was B. variabilis. This faunal similarity probably occurs because subterranean environments offer similar conditions also in regions of different climatic zones. It also means that the dispersal mechanism of BF, occurring through the transport of juvenile specimens (propagules) in a cryptic stage, is effective at a global scale and allows penetration into highly confined environments [120,121]. 
Table 2. List of the main foraminiferal species mentioned in this study, recorded in marine caves and provenance region.

\begin{tabular}{|c|c|c|c|c|c|c|c|}
\hline Species & 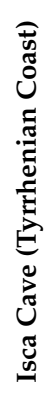 & 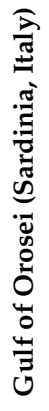 & 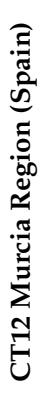 &  & 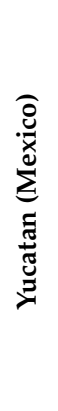 & 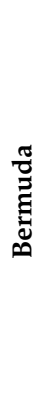 & 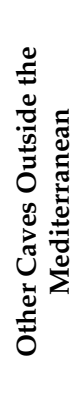 \\
\hline Adelosina spp. & $X$ & & & & & & \\
\hline Ammodiscus tenuis (Brady, 1881) & & & & & & $X$ & \\
\hline Ammonia beccarii (Linnaeus, 1758 ) & & & & & & & $X$ \\
\hline Ammonia inflata (Seguenza, 1862) & & $X$ & & & & & \\
\hline Ammonia tepida (Cushman, 1926) & & & & & $X$ & & \\
\hline Ammonia spp. & & & & & & & $X$ \\
\hline Amphistegina radiata (Fichtel \& Moll, 1798) & & & & & & & $X$ \\
\hline Baculogipsina sphaerulata (Parker \& Jones, 1860) & & & & & & & $X$ \\
\hline Calcarina spp. & & & & & & & $X$ \\
\hline Bolivina spp. & & $X$ & & & & $X$ & \\
\hline Bolivina variabilis (Williamson, 1858) & & $X$ & $X$ & & & $\mathrm{X}$ & \\
\hline Cibicides refulgens Montfort, 1808 & & & & & & $X$ & \\
\hline Cornuspiramia adherens (Le Calvez, 1935) & & & & $X$ & & & \\
\hline Cribrostomoides jeffreysii (Williamson, 1858) & & $X$ & & & & & \\
\hline Eggerelloides advenus (Cushman, 1922) & & $X$ & & & & & \\
\hline Elphidium crispum (Linnaeus, 1758) & & $X$ & & & & & \\
\hline Elphidium spp. & & & & & & $\mathrm{X}$ & $X$ \\
\hline Gavelinopsis praegeri (Heron-Allen \& Earland, 1913) & & $X$ & $X$ & & & & \\
\hline Globigerina sp. & & & & & & & $X$ \\
\hline $\begin{array}{l}\text { Jadammina macrescens (Brady, 1870) accepted as Entzia } \\
\text { macrescens (Brady, 1870) }\end{array}$ & & & & & $X$ & & \\
\hline Lepidodeuterammina ochracea (Williamson, 1858) & & $X$ & & & & & \\
\hline $\begin{array}{l}\text { Lobatula lobatula (Walker \& Jacob, 1798) synonim of } \\
\text { Cibicidoides lobatulus (Walker \& Jacob, 1798) }\end{array}$ & & & $X$ & & & & $X$ \\
\hline $\begin{array}{l}\text { Melonis barleeanus (Williamson, 1858) accepted as Melonis } \\
\text { affinis (Reuss, 1851) }\end{array}$ & $X$ & & & & & $X$ & \\
\hline Miliolinella subrotunda (Montagu, 1803) & & & $X$ & & & & \\
\hline Miniacina miniacea (Pallas, 1766) & $X$ & & & $\mathrm{X}$ & & & \\
\hline Nouria polymorphinoides Heron-Allen \& Earland, 1914 & & $X$ & & & & & \\
\hline Patellina corrugata Williamson, 1858 & & & $X$ & & & & \\
\hline Peneroplis planatus (Fichtel \& Moll, 1798) & & $X$ & & & & & $X$ \\
\hline Peneroplis pertusus (Forsskål in Niebuhr, 1775) & & $X$ & & & & & \\
\hline Planogypsina acervalis (Brady, 1884) & & & & $X$ & & & \\
\hline Polysaccammina ipohalina Scott, 1976 & & & & & & $X$ & \\
\hline Pseudothurammina limnetis (Scott \& Medioli, 1980) & & & & & & $X$ & \\
\hline Quinqueloculina spp. & & & & & & $\mathrm{X}$ & \\
\hline $\begin{array}{l}\text { Reophax dentaliniformis (Brady, 1881) accepted as Nodulina } \\
\text { dentaliniformis (Brady, 1881) }\end{array}$ & & $\mathrm{X}$ & & & & & \\
\hline Rhizammina sp. & $X$ & & & & & & \\
\hline Rosalina bradyi (Cushman, 1915) & & $X$ & & & & & \\
\hline Rosalina spp. & & $X$ & & & & $X$ & \\
\hline $\begin{array}{l}\text { Sigmoilina tenuis (Cžjžek, 1848) accepted as Spirosigmoilina } \\
\text { tenuis (Cžjžek, 1848) }\end{array}$ & & & & & & $X$ & \\
\hline Sejunctella sp. & & & $X$ & & & & \\
\hline Spirillina vivipara Ehrenberg, 1843 & & & $X$ & & & $X$ & \\
\hline Spirophthalmidium emaciatum (Haynes, 1973) & & & $X$ & & & $\mathrm{X}$ & \\
\hline Textularia bocky & & & $X$ & & & & \\
\hline Textularia spp. & $X$ & & & & & & \\
\hline Trochammina inflata (Montagu, 1808) & & & & & & $\mathrm{X}$ & \\
\hline Tubinella inornata (Brady, 1884) & & & $X$ & & & & \\
\hline
\end{tabular}




\begin{abstract}
Author Contributions: Supervision, E.R.; writing—original draft preparation, E.R., L.B. and M.P. All authors have read and agreed to the published version of the manuscript.
\end{abstract}

Funding: This research received no external funding.

Conflicts of Interest: The authors declare no conflict of interest.

\title{
References
}

1. Bakalowicz, M. Karst groundwater: A challenge for new resources. Hydrogeol. J. 2005, 13, 148-160. [CrossRef]

2. Bakalowicz, M. Karst and karst groundwater resources in the Mediterranean. Environ. Earth Sci. 2015, 74, 5-14. [CrossRef]

3. Goldscheider, N.; Chen, Z.; Auler, A.S.; Bakalowicz, M.; Broda, S.; Drew, D.; Hartmann, J.; Jiang, G.; Moosdorf, N.; Stevanovic, Z.; et al. Global distribution of carbonate rocks and karst water resources. J. Hydrogeol. 2020, 28, 1661-1677. [CrossRef]

4. Stevanovic, Z. Global distribution and use of water from karst aquifers. In Advances in Karst Research: Theory, Fieldwork and Applications; Parise, M., Gabrovsek, F., Kaufmann, G., Ravbar, N., Eds.; Geological Society of London: London, UK, 2018; pp. 217-236.

5. Stevanovic, Z. Karst waters in potable water supply: A global scale overview. Environ. Earth Sci. 2019, 78, 662. [CrossRef]

6. Fleury, P.; Bakalowicz, M.; de Marsily, G. Submarine springs and coastal karst aquifers: A review. J. Hydrol. 2007, 339, 79-92. [CrossRef]

7. Mijatovic, B. The groundwater discharge in the Mediterranean karst coastal zones and freshwater tapping: Set problems and adopted solutions. Case studies. Environ. Geol. 2007, 51,737-742. [CrossRef]

8. Parise, M.; Ravbar, N.; Živanovic, V.; Mikszewski, A.; Kresic, N.; Mádl-Szonyi, J.; Kukuric, N. Hazards in Karst and Managing Water Resources Quality. In Karst Aquifers-Characterization and Engineering; Professional Practice in Earth Sciences; Stevanovic, Z., Ed.; Springer: Berlin/Heidelberg, Germany, 2015; pp. 601-687.

9. Parise, M.; Gabrovsek, F.; Kaufmann, G.; Ravbar, N. Recent advances in karst research: From theory to fieldwork and applications. In Advances in Karst Research: Theory, Fieldwork and Applications; Parise, M., Gabrovsek, F., Kaufmann, G., Ravbar, N., Eds.; Geological Society of London: London, UK, 2018; pp. 1-24.

10. Pinault, J.L.; Doerfliger, N.; Ladouche, B.; Bakalowicz, M. Characterizing a coastal karst aquifer using an inverse modeling approach: The saline springs of Thau, southern France. Water Resour. Res. 2004, 40. [CrossRef]

11. Olarinoye, T.; Gleeson, T.; Marx, V.; Seeger, S.; Adinehvand, R.; Allocca, V.; Andreo, B.; Apaéstegui, J.; Apolit, C.; Arfib, B.; et al. Global karst springs hydrograph dataset for research and management of the world's fastest-flowing groundwater. Sci. Data 2020, 7, 59. [CrossRef]

12. Ford, D.C.; Williams, P. Karst Hydrogeology and Geomorphology; Wiley: Chichester, UK, 2007.

13. Palmer, A.N. Cave Geology; Cave Books: Dayton, OH, USA, 2007.

14. Harris, J.; Mylroie, J.; Carew, J. Banana holes: Unique karst features of the Bahamas. Carbonates Evaporites 1995, 10, 215-224. [CrossRef]

15. Del Prete, S.; Iovine, G.; Parise, M.; Santo, A. Origin and distribution of different types of sinkholes in the plain areas of Southern Italy. Geodin. Acta 2010, 23, 113-127. [CrossRef]

16. Parise, M. Hazards in karst. Sustainability of the karst environment. Dinaric karst and other karst regions. In Proceedings of the International Interdisciplinary Scientific Conference, Plitvice Lakes, Croatia, 23-26 September 2009; Bonacci, O., Ed.; Series on Groundwater no. 2. IHP-UNESCO: Paris, France, 2010; pp. 155-162.

17. Parise, M. Sinkholes. In Encyclopedia of Caves, 3rd ed.; White, W.B., Culver, D.C., Pipan, T., Eds.; Academic Press: Cambridge, MA, USA; Elsevier: Amsterdam, The Netherlands, 2019; pp. 934-942.

18. Gutiérrez, F.; Parise, M.; De Waele, J.; Jourde, H. A review on natural and human-induced geohazards and impacts in karst. Earth-Sci. Rev. 2014, 138, 61-88. [CrossRef]

19. Viles, H.A. Recent advances in field and experimental studies of rock weathering. Z. Geomorphol. 2000, 120, 343-368.

20. Nicholson, D.T. Pore properties as indicator of breakdown mechanism in experimentally weathered limestones. Earth Surf. Process. Landf. 2001, 26, 819-838. [CrossRef]

21. Gomez-Pujol, L.; Fornós, J.J.; Swantesson, J.O.H. Rock surface millimeter-scale roughness and weathering of supratidal Mallorcan carbonate coasts (Balearic Islands). Earth Surf. Process. Landf. 2006, 31, 1792-1801. [CrossRef]

22. Calcaterra, D.; Parise, M. Weathering as a Predisposing Factor to Slope Movements; sp. publ. 23; Calcaterra, D., Parise, M., Eds.; Geological Society of London: London, UK, 2010; p. 233.

23. Naylor, L.A.; Coombes, M.A.; Viles, H.A. Reconceptualising the role of organisms in the erosion of rock coasts: A new model. Geomorphology 2012, 157-158, 17-30. [CrossRef]

24. Moses, C.; Robinson, D.; Barlow, J. Methods for measuring rock surface weathering and erosion: A critical review. Earth Sci. Rev. 2014, 135, 141-161. [CrossRef]

25. Waelbroeck, C.; Labeyrie, L.; Michel, E.; Duplessy, J.C.; McManus, J.F.; Lambeck, K.; Balbon, E.; Labracherie, M. Sea-level and deep-water temperature changes derived from benthic foraminifera isotopic records. Quat. Sci. Rev. 2002, 21, 295-305. [CrossRef]

26. Palmer, A.N. Origin and morphology of limestone caves. Geol. Soc. Am. Bull. 1991, 103, 1-21. [CrossRef]

27. Klimchouk, A.B.; Ford, D.C.; Palmer, A.N.; Dreybrodt, W. Speleogenesis: Evolution of Karst Aquifers; National Speleological Society: Huntsville, AL, USA, 2000 
28. Stock, J.H.; Iliffe, T.M.; Williams, D. The concept “anchialine" reconsidered. Stygologia 1986, 2, 90-92.

29. van Hengstum, P.J.; Scott, D.B. Ecology of foraminifera and habitat variability in an underwater cave: Distinguishing anchialine versus submarine cave environments. J. Foraminifer. Res. 2011, 41, 201-229. [CrossRef]

30. van Hengstum, P.J.; Scott, D.B.; Grocke, D.R.; Charette, M.A. Sea level controls sedimentation and environments in coastal caves and sinkholes. Mar. Geol. 2011, 286, 35-50. [CrossRef]

31. Choquette, P.W.; Pray, L.C. Geologic nomenclature and classification of porosity in sedimentary carbonates. Amer. Ass. Petrol. Geol. Bull. 1970, 54, 207-250.

32. Mylroie, J.E.; Mylroie, J.R. Void development on carbonate coasts: Creation of anchialine habitats. Hydrobiologia 2011, 677, 15-32. [CrossRef]

33. Jenson, J.W.; Keel, T.M.; Mylroie, J.R.; Mylroie, J.E.; Stafford, K.W.; Taborosi, D.; Wexel, C. Karst of the Mariana Islands: The interaction of tectonics, glacioeustasy and freshwater/sea-water mixing in island carbonates. Geol. Soc. Am. Spec. Pap. 2006, 404, 129-138.

34. Mylroie, J.R.; Mylroie, J.E. Development of the carbonate island karst model. J. Cave Karst Stud. 2007, 69, 59-75.

35. Arfib, B.; de Marsily, G.; Ganoulis, J. Locating the zone of saline intrusion in a coastal karst aquifer using spring flow data. Ground Water 2007, 45, 28-35. [CrossRef]

36. Beddows, P.A.; Smart, P.L.; Whitaker, F.F.; Smith, S.L. Decoupled fresh-saline circulation of a coastal carbonate aquifer: Spatial patterns of temperature and specific electrical conductivity. J. Hydrol. 2007, 16, 18-32. [CrossRef]

37. Back, W.; Hanshaw, B.B.; Herman, J.S.; Van Driel, J.N. Differential dissolution of a Pleistocene reef in the groundwater mixing zone of coastal Yucatan, Mexico. Geology 1986, 14, 137-140. [CrossRef]

38. Raeisi, E.; Mylroie, J.E. Hydrodynamic behavior of caves formed in the freshwater lens of carbonate islands. Carbonates Evaporites 1995, 10, 207-214. [CrossRef]

39. Mylroie, J.E.; Carew, J.L. The flank margin model for dissolution cave development in carbonate platforms. Earth Surf. Process. Landf. 1990, 15, 413-424. [CrossRef]

40. Carew, J.L.; Mylroie, J.E. Quaternary tectonic stability of the Bahamian Archipelago: Evidence from fossil coral reefs and flank margin caves. Quat. Sci. Rev. 1995, 14, 144-153. [CrossRef]

41. Labourdette, R.; Lascu, I.; Mylroie, J.; Roth, M. Process-like modeling of flank margin caves: From genesis to burial evolution. J. Sediment. Res. 2007, 77, 965-979. [CrossRef]

42. Waterstrat, W.J.; Mylroie, J.E.; Owen, A.M.; Mylroie, J.R. Coastal caves in Bahamian eolian calcarenites: Differentiating between sea caves and flank margin caves using quantitative morphology. J. Caves Karst Stud. 2010, 72, 61-74. [CrossRef]

43. Mylroie, J.E.; Carew, J.J. Solution conduits as indicators of late Quaternary Sea level position. Quat. Sci. Rev. 1988, 7, 55-64. [CrossRef]

44. Dipova, N.; Okudan, E.S. Sea caves, flank margin caves and tufa caves observed on Antalya coastal cliffs. J. Coastal Res. 2011, 61, 382-386. [CrossRef]

45. Gulley, J.D.; Martin, J.B.; Moore, P.J.; Brown, A.; Spellman, P.D.; Ezell, J. Heterogeneous distributions of $\mathrm{CO}_{2}$ may be more important for dissolution of karstification in coastal eogenetic limestone than mixing dissolution. Earth Surf. Process. Landf. 2015, 40, 1057-1071. [CrossRef]

46. Gulley, J.D.; Martin, J.B.; Brown, A. Organic carbon inputs, common ions and degassing: Rethinking mixing dissolution in coastal eogenetic carbonate aquifers. Earth Surf. Process. Landf. 2016, 41, 2098-2110. [CrossRef]

47. Otoničar, B.; Buzjak, N.; Mylroie, J.; Mylroie, J. Flank margin cave development in carbonate talus breccia facies: An example from Cres Island, Croatia. Acta Carsologica 2010, 39, 79-91. [CrossRef]

48. White, S.; Webb, J.A. The influence of tectonics on flank margin cave formation on a passive continental margin: Naracoorte, Southeastern Australia. Geomorphology 2015, 229, 58-72. [CrossRef]

49. Suric, M.; Juracic, M.; Horvatincic, N.; Bronic, I.K. Late-Pleistocene-Holocene sea level rise and the pattern of coastal karst inundation: Records from submerged speleothems along the Eastern Adriatic Coast (Croatia). Mar. Geol. 2005, 214, 163-175. [CrossRef]

50. Mylroie, J.E.; Mylroie, J.R.; Nelson, C.S. Flank margin cave development in telogenetic limestones of New Zealand. Acta Carsologica 2008, 37, 15-40. [CrossRef]

51. Arriolabengoa, M.; D’Angeli, I.M.; De Waele, J.; Parise, M.; Ruggieri, R.; Sanna, L.; Madonia, G.; Vattano, M. Flank Margin Caves in Telogenetic Limestones in Italy. In Proceedings of the 17th International Congress of Speleology, Sydney, Australia, 23-29 July 2017; Moore, K., White, S., Eds.; Australian Speleological Federation Inc.: Sydney, Australia, 2017; Volume 2, pp. $289-292$.

52. Bonacci, O.; Pipan, T.; Culver, D.C. A framework for karst ecohydrology. Environ. Geol. 2009, 56, 891-900. [CrossRef]

53. Northup, D.E.; Lavoie, K.H. Geomicrobiology of caves: A review. Geomicrobiol. J. 2001, 18, 199-222.

54. Barton, H.A.; Northup, D.E. Geomicrobiology in cave environments: Past, current and future perspectives. J. Cave Karst Stud. 2007, 69, 163-178.

55. Culver, D.C.; Pipan, T. The Biology of Caves and Other Subterranean Habitats; Oxford University Press: Oxford, UK, 2009.

56. Viles, H.A. Microbial geomorphology: A neglected link between life and landscape. Geomorphology 2012, 157-158, 6-16. [CrossRef]

57. Phillips, J.D. Biogeomorphology and contingent ecosystem engineering in karst landscapes. Prog. Phys. Geogr. 2016, 40, 503-526. [CrossRef] 
58. Mejía-Ortíz, L.M.; Pipan, T.; Culver, D.C.; Sprouse, P. The blurred line between photic and aphotic environments: A large Mexican cave with almost no dark zone. Int. J. Speleol. 2018, 47, 69-80. [CrossRef]

59. D'Angeli, I.M.; Naylor, L.A.; Lee, M.; Miller, A.Z.; Mylroie, J.; De Waele, J. Light attenuation as a control for microbiogeomorphic features: Implications for coastal cave speleogenesis. Geomorphology 2020, 354, 107054. [CrossRef]

60. Gerovasileiou, V.; Bianchi, N. Mediterranean marine caves: A synthesis of current knowledge. In Oceanography and Marine Biology: An Annual Review; Hawkins, S.J., Lemasson, A.J., Allcock, A.L., Bates, A.E., Byrne, M., Evans, A.J., Firth, L.B., Marzinelli, E.M., et al., Eds.; Taylor and Francis: London, UK, 2021; Volume 59, pp. 1-88.

61. Cavalier-Smith, T. Kingdom Chromista and its eight phyla: A new synthesis emphasising periplastid protein targeting, cytoskeletal and periplastid evolution, and ancient divergences. Protoplasma 2018, 255, 297-357. [CrossRef]

62. Hayward, B.W.; Le Coze, F.; Vachard, D.; Gross, O. World Foraminifera Database. Available online: http://www.marinespecies. org/foraminifera (accessed on 21 September 2021).

63. Murray, J.W. Biodiversity of living benthic foraminifera: How many species are there? Mar. Micropal. 2007, 64, 163-176. [CrossRef]

64. Dias, B.B.; Hart, M.B.; Smart, C.W.; Hall-Spencer, J.M. Modern sea-water acidification: The response of foraminifera to high-CO 2 conditions in the Mediterranean Sea. J. Geol. Soc. Lond. 2010, 167, 843-846. [CrossRef]

65. Alve, E. Colonization of new habitats by benthic foraminifera: A review. Earth Sci. Rev. 1999, 46, 167-185. [CrossRef]

66. Murray, J.W. Ecology and Palaeoecology of Benthic Foraminifera; Longman Scientific \& Technical: London, UK, $1991 ;$ pp. 1-397.

67. Murray, J.W. Ecology and Applications of Benthic Foraminifera; Cambridge University Press: New York, NY, USA, $2006 ;$ pp. 1-426.

68. Schönfeld, J.; Alve, E.; Geslin, E.; Jorissen, F.; Korsun, S.; Spezzaferri, S. Members of the FOBIMO group, 2012. The FOBIMO (Foraminiferal Bio-Monitoring) initiative-Towards a standardized protocol for soft-bottom benthic foraminiferal monitoring studies. Mar. Micropaleontol. 2012, 94-95, 1-13. [CrossRef]

69. Bergamin, L.; Di Bella, L.; Ferraro, L.; Frezza, V.; Pierfranceschi, G.; Romano, E. Benthic foraminifera in a coastal marine area of the eastern Ligurian Sea (Italy): Response to environmental stress. Ecol. Indic. 2019, 96, 16-31. [CrossRef]

70. de Nooijer, L.J.; Duijnstee, I.A.P.; van der Zwaan, G.J. Novel application of MTT reduction: A viability assay for temperate shallow-water benthic foraminifera. J. Foraminifer. Res. 2006, 36, 195-200. [CrossRef]

71. Bernhard, J.M.; Ostermann, D.R.; Williams, D.S.; Blanks, J.K. Comparison of two methods to identify live benthic foraminifera: A test between Rose Bengal and CellTracker Green with implications for stable isotope paleoreconstructions. Paleoceanography 2006, 21, PA4210. [CrossRef]

72. Scott, D.B.; Medioli, F.S.; Schafer, C.T. Monitoring in Coastal Environments Using Foraminifera and Thecamoebian Indicators; Cambridge University Press: New York, NY, USA, 2001; pp. 1-177.

73. Dolven, J.K.; Alve, E.; Rygg, B.; Magnusson, J. Defining past ecological status and in situ reference conditions using benthic foraminifera: A case study from the Oslofjord, Norway. Ecol. Indic. 2013, 29, 219-233. [CrossRef]

74. Avnaim-Katav, S.; Almogi-Labin, A.; Sandler, A.; Sivan, D. Benthic foraminifera as palaeoenvironmental indicators during the last million years in the eastern Mediterranean inner shelf. Palaeogeogr. Palaeoclimatol. Palaeoecol. 2013, 386, 512-530. [CrossRef]

75. Sousa, S.H.M.; Yamashita, C.; Semensatto, D.L., Jr.; Santarosa, A.C.A.; Iwai, F.S.; Omachi, C.Y.; Disaró, S.T.; Martins, M.V.A.; Barbosa, C.F.; Bonetti, C.H.C.; et al. Members of the BIOFOM group. Opportunities and challenges in incorporating benthic foraminifera in marine and coastal environmental biomonitoring of soft sediments: From science to regulation and practice. $J$. Sediment. Environ. 2020, 5, 267-275. [CrossRef]

76. Zeppilli, D.; Leduc, D.; Fontanier, C.; Fontaneto, D.; Fuchs, S.; Gooday, A.J.; Goineau, A.; Ingels, J.; Ivanenko, V.N.; Møbjerg Kristensen, R.; et al. Characteristics of meiofauna in extreme marine ecosystems: A review. Mar. Biodiv. 2018, 48, 35-71. [CrossRef]

77. Proctor, C.J.; Smart, P.L. A dated cave sediment record of Pleistocene transgressions on Berry Head, Southwest England. J. Quat. Sci. 1991, 6, 233-244. [CrossRef]

78. Rosso, A.; Sanfilippo, R.; Ruggieri, R.; Maniscalco, R.; Vertino, A. Exceptional record of submarine cave communities from the Pleistocene of Sicily (Italy). Lethaia 2014, 48, 133-144. [CrossRef]

79. Rosso, A.; Sanfilippo, R.; Vertino, A.; Zibrowius, H. Hanging coral gardens of a Tyrrhenian submarine cave from Sicily (Italy). Boll. Soc. Paleont. It. 2017, 56, 1-12.

80. Rubin, C.M.; Horton, B.; Sieh, K.; Pilarczyk, J.E.; Daly, P.; Ismail, N.; Parnell, A.C. Highly variable recurrence of tsunamis in the 7400 years before the 2004 Indian Ocean tsunami. Nat. Commun. 2017, 8, 16019. [CrossRef] [PubMed]

81. Switzer, A.D.; Felix, R.P.; Soria, J.L.A.; Shaw, T.A. A comparative study of the 2013 typhoon Haiyan overwash sediments from a coastal cave and beach system at Salcedo, Eastern Samar, central Philippines. Mar. Geol. 2020, 419, 106083. [CrossRef]

82. van Hengstum, P.J.; Scott, D.B.; Javaux, E.J. Foraminifera in elevated Bermudian caves provide further evidence for $+21 \mathrm{~m}$ eustatic sea level during Marine Isotope Stage. Quat. Sci. Rev. 2009, 28, 1850-1860. [CrossRef]

83. Omori, A.; Kitamura, A.; Fujita, K.; Honda, K.; Yamamoto, N. Reconstruction of light conditions within a submarine cave during the past 7000 years based on the temporal and spatial distribution of algal symbiont-bearing large benthic foraminifers. Palaeogeogr. Palaeoclimatol. Palaeoecol. 2010, 292, 443-452. [CrossRef]

84. van Hengstum, P.J.; Scott, D.B. Sea-level rise and coastal circulation controlled Holocene groundwater development in Bermuda and caused a meteoric lens to collapse 1600 years ago. Mar Micropal. 2012, 90-91, 29-43. [CrossRef]

85. van Hengstum, P.J.; Reinhardt, E.G.; Beddows, P.A.; Schwarcz, H.P.; Gabriel, J.J. Foraminifera and testate amoebae (thecamoebians) in an anchialine cave: Surface distributions from Aktun Ha (Carwash) cave system, Mexico. Limnol. Oceanogr. 2009, 54, 391-396. [CrossRef] 
86. Brankovits, D.; Little, S.N.; Winkler, T.S.; Tamalavage, A.E.; Mejía-Ortíz, L.M.; Maupin, C.R.; Yáñez-Mendoza, G.; van Hengstum, P.J. Changes in organic matter deposition can impact benthic marine meiofauna in karst subterranean estuaries. Front. Environ. Sci. 2021, 9, 670914. [CrossRef]

87. van Hengstum, P.J.; Reinhardt, E.G.; Beddows, P.A.; Huang, R.J.; Gabriel, J.J. Thecamoebians (testate amoebae) and foraminifera from three anchialine cenotes in Mexico: Low salinity (1.5-4.5 psu) faunal transitions. J. Foraminifer. Res. $2008,38,305-317$. [CrossRef]

88. Javaux, E.J.; Scott, D.B. Illustration of modern benthic foraminifera from Bermuda and remarks on distribution in other subtropical/tropical Areas. Palaeontologia Electronica 2003, 6, 29.

89. Little, S.N.; van Hengstum, P.J. Intertidal and subtidal benthic foraminifera in flooded caves: Implications for reconstructing coastal karst aquifers and cave paleoenvironments. Mar Micropal. 2019, 149, 19-34. [CrossRef]

90. Cresswell, J.N.; van Hengstum, P.J. Habitat partitioning in the marine sector of karst subterranean estuaries and Bermuda's marine caves: Benthic foraminiferal evidence. Front. Environ. Sci. 2021, 8, 594554. [CrossRef]

91. Woodward, J.C.; Lewin, J. Karst geomorphology and environmental change. In The Physical Geography of the Mediterranean, 1st ed.; Woodwars, J., Ed.; Oxford University Press: Oxford, UK, 2009; pp. 287-317.

92. Belmonte, G.; Ingrosso, G.; Poto, M.; Quarta, G.; D’Elia, M.; Onorato, R.; Calcagnile, L. Biogenic stalactites in submarine caves at the Cape of Otranto (SE Italy): Dating and hypothesis on their formation. Marine Ecology 2009, 30, 376-382. [CrossRef]

93. Guglielmo, R.; Bergamasco, A.; Minutoli, R.; Patti, F.P.; Belmonte, G.; Spanò, N.; Zagami, G.; Bonanzinga, V.; Guglielmo, L.; Granata, A. The Otranto Channel (South Adriatic Sea), a hot-spot area of plankton biodiversity: Pelagic polychaetes. Sci. Rep. 2019, 9, 19490. [CrossRef] [PubMed]

94. Balduzzi, A.; Cattaneo, R. Estimation par relèvements photographiques de la distribution de Miniacina miniacea (Sarcomastigophora, Foraminiferida) dans une grotte sous-marine du Golfe de Naples. In Rapports et Proces-Verbaux des Reunions; Commission International pour l’Exploration Scientifique de la Mer Méditerranée: Monaco, Spain, 1985; Volume 29, pp. 127-129.

95. Gerovasileiou, V.; Chintiroglou, C.C.; Vafidis, D.; Koutsoubas, D.; Sini, M.; Dailianis, T.; Issaris, Y.; Akritopoulou, E.; Dimarchopoulou, D.; Voultsiadou, E. Census of biodiversity in marine caves of the eastern Mediterranean Sea. Medit. Mar. Sci. 2015, 16, 245-265. [CrossRef]

96. Martí, R.; Uriz, M.J.; Ballesteros, E.; Turon, X. Benthic assemblages in two Mediterranean caves: Species diversity and coverage as a function of abiotic parameters and geographic distance. J. Mar. Biol. Ass. UK 2004, 84, 557-572. [CrossRef]

97. Bussotti, S.; Terlizzi, A.; Fraschetti, S.; Belmonte, G.; Boero, F. Spatial and temporal variability of sessile benthos in shallow Mediterranean marine caves. Mar. Ecol. Prog. Ser. 2006, 325, 109-119. [CrossRef]

98. Ricci, S.; Cadeddu, B.; Melis, P.; Manconi, R. The Azzurra cave (Capri): First notes on fouling of Nimpaea. Biol. Mar. Mediterr. 2013, 20, 150-151.

99. Sanfilippo, R.; Rosso, A.; Guido, A.; Mastandrea, A.; Russo, F.; Riding, R.; Taddei Ruggiero, E. Metazoan/microbial biostalactites from present-day submarine caves in the Mediterranean Sea. Mar. Ecol. 2015, 36, 1277-1293. [CrossRef]

100. Denitto, F.; Terlizzi, A.; Belmonte, G. Settlement and primary succession in a shallow submarine cave: Spatial and temporal benthic assemblage distinctness. Mar. Ecol. 2007, 28, 35-46. [CrossRef]

101. Rosso, A.; Gerovasileiou, V.; Sanfilippo, R.; Guido, A. bryozoan assemblages from two submarine caves in the Aegean Sea (Eastern Mediterranean). Mar. Biodiv. 2019, 49, 707-726. [CrossRef]

102. Taddei Ruggiero, E. Foraminifera of bio and thanatocoenoses from the submarine Isca cave, Sorrento peninsula Southern Italy. Mem. Descr. Carta Geol. d'It. 1994, 52, 373-388.

103. Romano, E.; Bergamin, L.; Di Bella, L.; Frezza, V.; Marassich, A.; Pierfranceschi, G.; Provenzani, C. Benthic foraminifera as proxies of marine influence in the Orosei marine caves (Sardinia, Italy). Aquat. Conserv. 2020, 30, 701-716. [CrossRef]

104. Scatolini, A. Sardegna, La Grotta del Bel Torrente ha Raggiunto 8.6 km di Sviluppo e Altri 1500m Sono Stati Appena Esplorati. Scintilena. Available online: https:/ / www.scintilena.com/sardegna-la-grotta-del-bel-torrente-ha-raggiunto-8-6-km-di-sviluppoe-altri-1500m-sono-stati-appena-esplorati/10/29 (accessed on 4 November 2021).

105. Bergamin, L.; Marassich, A.; Provenzani, C.; Romano, E. Foraminiferal ecozones in two submarine caves of the Orosei Gulf (Sardinia, Italy). Rend. Lincei Sci. Fis. Nat. It. 2018, 29, 547-557. [CrossRef]

106. Romano, E.; Bergamin, L.; Pierfranceschi, G.; Provenzani, C.; Marassich, A. The distribution of benthic foraminifera in Bel Torrente submarine cave (Sardinia, Italy) and their environmental significance. Mar. Environ. Res. 2018, 133, 114-127. [CrossRef]

107. De Waele, J.; Schafheutle, M.; Waelde, T. Speleogenesis of extensive underwater caves along the gulf of Orosei (Central-east Sardinia, Italy). In Proceedings of the 15th International Congress of Speleology, Kerrville, TX, USA, 19-26 July 2009; Volume 1, pp. $469-474$.

108. Sanna, L.; De Waele, J. Karst landscape and caves in the Gulf of Orosei (Central-East Sardinia): A scientific and cultural resource. In Cuevas: Patrimonio, Naturaleza, Cultura y Turismo; Durán, J.J., Carrasco, F., Eds.; Asociación de Cuevas Turísticas Españolas: Madrid, Spain, 2010; pp. 351-362.

109. Buosi, C.; Armynot du Châtelet, E.; Cherchi, A. Benthic foraminiferal assemblages in the current-dominated strait of Bonifacio (Mediterranean Sea). J. Foraminifer. Res. 2012, 42, 39-55. [CrossRef]

110. Buosi, C.; Cherchi, A.; Ibba, A.; Marras, B.; Marrucci, A.; Schintu, M. Benthic foraminiferal assemblages and sedimentological characterization of the coastal system of the Cagliari area (southern Sardinia, Italy). Boll. Soc. Paleontol. Ital. 2013, 52, 1-9. 
111. Buosi, C.; Cherchi, A.; Ibba, A.; Marras, B.; Marrucci, A.; Schintu, M. Preliminary data on benthic foraminiferal assemblages and sedimentological characterization from some polluted and unpolluted coastal areas of Sardinia (Italy). Boll. Soc. Paleontol. Ital. 2013, 52, 35-44.

112. Cherchi, A.; Da Pelo, S.; Ibba, A.; Mana, D.; Buosi, C.; Floris, N. Benthic foraminifera response and geochemical characterization of the coastal environment surrounding the polluted industrial area of Portovesme (South-Western Sardinia, Italy). Mar. Pollut. Bull. 2009, 59, 281-296. [CrossRef]

113. Romano, E.; Bergamin, L.; Di Bella, L.; Frezza, V.; Pierfranceschi, G.; Marassich, A.; Provenzani, C. Benthic foraminifera as environmental indicators in extreme environments: The marine cave of Bue Marino (Sardinia, Italy). Ecol. Indic. 2021, $120,106977$. [CrossRef]

114. Bergamin, L.; Taddei Ruggiero, E.; Pierfranceschi, G.; Andres, B.; Constantino, R.; Crovato, C.; D’Ambrosi, A.; Marassich, A.; Romano, E. Benthic foraminifera and brachiopods from a marine cave in Spain: Environmental significance. Medit. Mar. Sci. 2020, 21, 506-518. [CrossRef]

115. Gázquez, F.; Calaforra, J.M.; Rodríguez-Estrella, T.; Ros, A.; Llamusí, J.L.; Sánchez, J. Evidence for regional hypogene speleogenesis in Murcia (SE Spain). In Hypogene Karst Regions and Caves of the World, Cave and Karst Systems of the World; Klimchouk, A., Palmer, A.N., Waele, J.D., Auler, A.S., Audra, P., Eds.; Springer: Berlin/Heidelberg, Germany, 2017; pp. 85-97.

116. Gázquez, F.; Calaforra, J.M.; Ros, A.; Llamusí, J.L.; Sánchez, J. Hypogenic morphologies and speleothems in caves in the Murcia region, south-eastern Spain. Deepkarst 2016, 1-8.

117. Rosso, A.; Sanfilippo, R.; Taddei Ruggiero, E.; Di Martino, E. Faunas and ecological groups of Serpuloidea, Bryozoa and Brachiopoda from submarine caves in Sicily (Mediterranean Sea). Boll. Soc. Paleontol. Ital. 2013, 52, 167-176.

118. McGann, M. Potential use of the benthic foraminifers Bulimina denudata and Eggerelloides advenus in marine sediment toxicity testing. Water 2021, 13, 775. [CrossRef]

119. Uthicke, S.; Momigliano, P.; Fabricius, K.E. High risk of extinction of benthic foraminifera in this century due to ocean acidification. Sci. Rep. 2013, 3, 1769. [CrossRef]

120. Alve, E.; Goldstein, S.T. Propagule transport as a key method of dispersal in benthic foraminifera (Protista). Limnol. Oceanogr. 2003, 48, 2163-2170. [CrossRef]

121. Alve, E.; Goldstein, S.T. Dispersal, survival and delayed growth of benthic foraminiferal propagules. J. Sea Res. 2010, 63, 36-51. [CrossRef] 